\title{
Kebiasaan makan pada anak gangguan pemusatan perhatian dan hiperaktivitas (GPPH) di Manado
}

\author{
${ }^{1}$ Christine Meilani \\ ${ }^{2}$ Herdy Munayang \\ ${ }^{2}$ Theresia M. D. Kaunang
}

\author{
${ }^{1}$ Kandidat Skripsi Fakultas Kedokteran Universitas Sam Ratulangi Manado \\ ${ }^{2}$ Bagian Psikiatri Fakultas Kedokteran Universitas Sam Ratulangi Manado \\ Email: cmeilani12291@gmail.com
}

\begin{abstract}
Attention deficit-hyperactivity disorder (ADHD) is characterized by poor attention which is not accordance to the development, or characteristics of hyperactivity and impulsivityor both that are not appropriate to age. ADHD is a behavioural disorder that is most common in children. ADHD can significantly change the most fundamental and important human behaviour, eating. This study was aimed to obtain the eating behaviour of children with ADHD in Manado. This was a quantitative study with a cross sectional design. There were 333 parents of children withh ADHD as respondents. The results showed that 237 children rarely eat foods containing preservatives and artificial food colorings; 231 children rarely eat foods with artificial sweetener; 310 children often eat high carbohydrate food; 201 children rarely eat foods containing casein; 252 children rarely eat foods containing amino acids; and 187 children rarely eat foods containing salicylic acid. Conclusion: Children with ADHD in Manado often eat high carbohydrate foods, but rarely consume foods or drinks containing preservatives, artificial colorings, artificial sweetener, casein, amino acids, and salicylic acid.
\end{abstract}

Keywords: eating behaviour, children, attention-deficit/hyperactivity disorder (ADHD).

\begin{abstract}
Abstrak: Gangguan pemusatan perhatian dan hiperaktivitas (GPPH) ditandai oleh rentang perhatian yang buruk dan tidak sesuai dengan perkembangan atau ciri hiperaktivitas dan impulsivitas atau keduanya yang tidak sesuai usia. GPPH merupakan gangguan tingkah laku yang paling banyak terjadi pada anak. GPPH dapat secara signifikan mengubah perilaku yang paling mendasar dan penting dari keprihatinan manusia, yakni makan. Penelitian ini bertujuan untuk mengetahui kebiasaan makan dari anak dengan GPPH di Manado. Jenis penelitian ialah kuantitatif dengan desain potong lintang. Terdapat 333 responden yaitu orang tua yang mempunyai anak dengan GPPH. Hasil penelitian mendapatkan 237 anak jarang mengonsumsi makanan berpengawet dan berpewarna buatan; 231 anak jarang mengonsumsi makanan berpemanis buatan; 310 anak sering mengonsumsi makanan tinggi karbohidrat; 201 anak jarang mengonsumsi makanan yang mengandung kasein; 252 anak jarang mengonsumsi makanan yang mengandung asam amino; serta 187 anak jarang mengonsumsi makanan yang mengandung asam salisilat. Simpulan: Anak dengan GPPH di Manado sering mengonsumsi makanan tinggi karbohidrat namun jarang mengonsumsi makanan atau minuman yang mengandung pengawet, pewarna, pemanis buatan, kasein, asam amino, dan asam salisilat.
\end{abstract}

Kata kunci: kebiasaan makan, anak, GPPH

Gangguan pemusatan perhatian dan hiperaktivitas (GPPH) atau Attention Deficit Hyperactivity Disorder (ADHD) ditandai oleh rentang perhatian yang buruk yang tidak sesuai dengan perkembangan atau ciri hiperaktivitas dan impulsivitas atau keduanya yang tidak sesuai dengan usia. Kriteria diagnostik yang harus terpenuhi untuk GPPH harus ada sekurang-kurangnya 6 bulan, menyebabkan gangguan dalam 
fungsi akademik atau sosial, dan terjadi sebelum usia 7 tahun. ${ }^{1,2}$

GPPH merupakan gangguan tingkah laku yang paling banyak terjadi pada anak. Berbagai penelitian terdahulu menunjukkan prevalensi gangguan ini berkisar dari $1 \%$ 29,2\%. ${ }^{3}$ Di Jakarta, prevalensi GPPH diantara anak Sekolah Dasar 26.2\%, proporsi terbesar ialah jenis gangguan tidak mampu memusatkan perhatian yaitu sebesar $15,9 \%{ }^{1}$

Penyebab GPPH belum diketahui pasti. Teori lama mengatakan penyebabnya antara lain ialah keracunan, komplikasi pada saat melahirkan, alergi terhadap gula dan beberapa jenis makanan, serta kerusakan pada otak. Walaupun demikian, masih banyak kasus GPPH yang tidak sesuai dengan penyebab tersebut. ${ }^{4}$ Para peneliti telah menemukan bahwa tingginya risiko mengalami GPPH berhubungan dengan genetik. Banyak gen terkait dengan GPPH, dan masing-masing gen memainkan peran kecil terhadap gangguan tersebut. ${ }^{5}$

GPPH dapat mengganggu berbagai aspek kehidupan seseorang, yaitu: kinerja pendidikan dan karir, gaya pengasuhan, asmara, kegiatan rekreasi, dan persahabatan. GPPH dapat juga secara signifikan mengubah salah satu perilaku yang paling mendasar dan penting dari keprihatinan manusia, yakni makan. ${ }^{6}$ Gangguan makan ialah kondisi serius yang berhubungan dengan perilaku makan terus-menerus yang berdampak negatif terhadap kesehatan, emosi dan kemampuan untuk berfungsi dalam bidang-bidang penting dari kehidupan.

Begitu banyak pendapat berbeda mengenai pola makan GPPH. Sebagian ahli mengatakan kebiasaan memakan makanan berpewarna buatan berpengaruh pada anak GPPH, tetapi yang lainnya menyatakan tidak berpengaruh., ${ }^{7,8}$ Beberapa ahli menyatakan, perubahan penataan pola makan dapat menjadi salah satu bentuk terapi penanganan GPPH. ${ }^{9-11}$

\section{METODE PENELITIAN}

Jensi penelitian ialah deskriptifkuantitatif dengan desain potong lintang untuk mengetahui gambaran kebiasaan makan pada anak GPPH. Variabel sebab dan akibat diambil dalam waktu yang sama.

\section{HASIL PENELITIAN DAN BAHASAN}

Dari 20 SD di Kota Manado, terdapat 5725 siswa yang dibagikan kuesioner untuk deteksi dini GPPH oleh peneliti. Terdapat sebanyak 646 siswa terdeteksi GPPH. Pada 646 siswa yang terdeteksi GPPH dibagikan kuesioner lanjutan untuk mengetahui kebiasaan makan pada anak GPPH dan didapatkan pengembalian kuesioner hanya sejumlah 333 kuesioner. Total sampel untuk penelitian ini yang telah memenuhi kriteria inklusi dan eksklusi sebesar 333 siswa (Gambar 1).

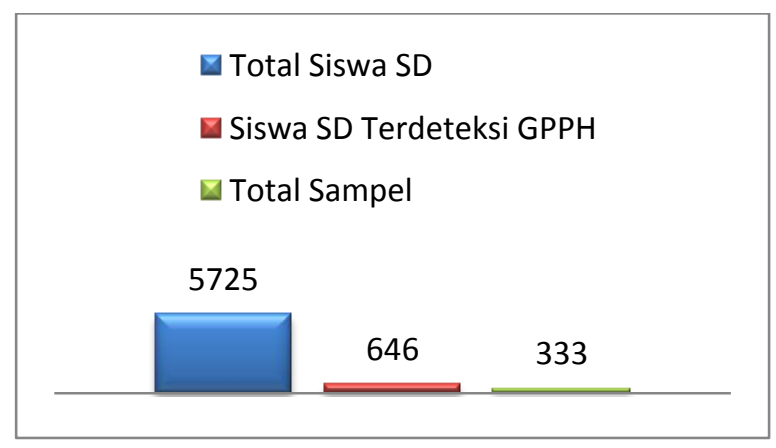

Gambar 1. Sampel penelitian kebiasaan makan anak GPPH (jumlah siswa)

Kebiasaan makan anak GPPH untuk makanan berpengawet dan pewarna buatan menunjukkan angka tertinggi pada yang jarang mengonsumsi (Gambar 1). Artinya, siswa hanya beberapa kali dalam seminggu mengonsumsi makanan berpengawet dan pewarna buatan.

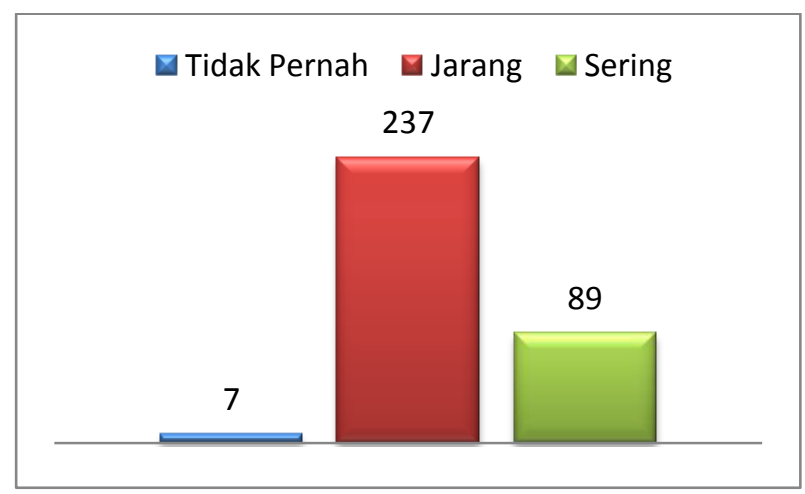

Gambar 2. Kebiasaan makan anak GPPH Makanan berpengawet dan pewarna buatan 
Makanan berpengawet dan pewarna buatan yang dicantumkan dalam kuesioner lanjutan ialah makanan cepat saji, makanan ringan, minuman ringan, serta makanan atau minuman berpewarna buatan.

Kebiasaan makan anak GPPH untuk makanan mengandung pemanis buatan mencapai nilai yang paling tinggi pada tingkat jarang mengonsumsi (Gambar 3). Artinya, dalam satu minggu, siswa hanya beberapa kali mengonsumsi makanan yang mengandung pemanis buatan, namun demikian, angka 99, dinilai cukup tinggi untuk sering mengonsumsi makanan berpemanis buatan. Makanan yang mengandung pemanis buatan dalam kuesioner yang dibagikan berupa cokelat dan permen/lollipop.

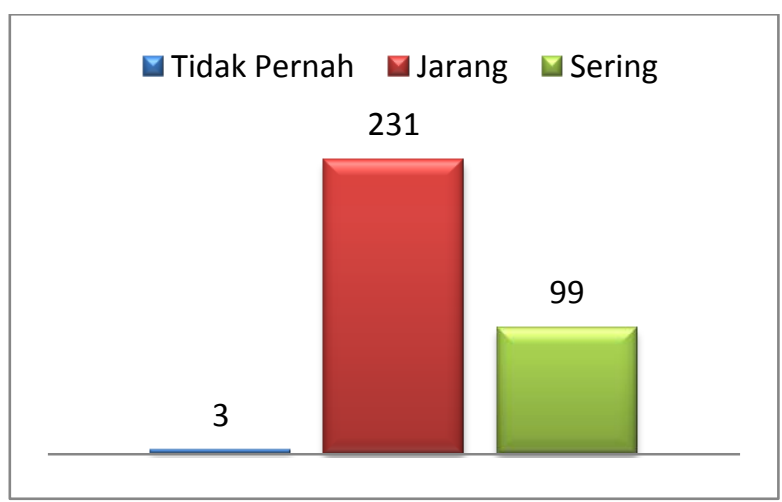

Gambar 3. Kebiasaan makan anak GPPH Makanan mengandung pemanis buatan

Kebiasaan makan anak GPPH untuk makanan tinggi karbohidrat mencapai angka yang paling tinggi pada tingkat sering (Gambar 4).

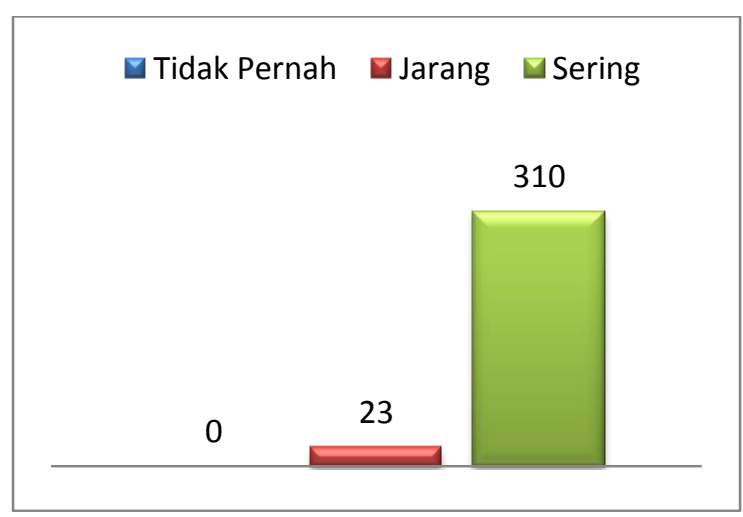

Gambar 4. Kebiasaan makan anak GPPH Makanan tinggi karbohidrat
Memang wajar, mengingat makanan pokok bangsa Indonesia ialah karbohidrat, yakni nasi putih. Terdapat 23 siswa yang tidak selalu atau dapat dikatakan jarang mengonsumsi karbohidrat. Makanan tinggi karbohidrat yang dicantumkan dalam kuesioner ialah roti/sereal gandum dan nasi putih.

Kebiasaan makan anak GPPH mengandung kasein memiliki peringkat tertinggi pada kategori jarang (201 siswa) disusul oleh kategori sering (122 siswa) (Gambar 5). Hal ini menunjukkan bahwa begitu banyak siswa SD, khususnya di Kota Manado yang hampir setiap hari mengonsumsi berbagai produk yang mengandung kasein. Makanan yang mengandung kasein pada kuesioner berupa keju, krim susu, dan susu sapi.

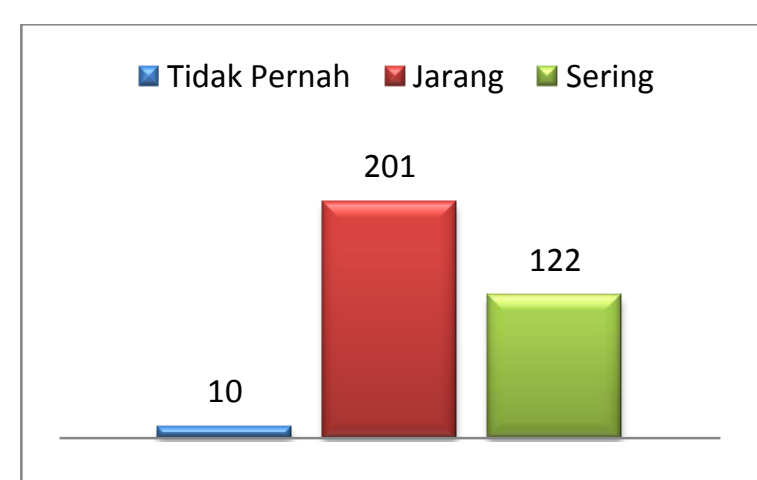

Gambar 5. Kebiasaan makan anak GPPH Makanan mengandung kasein

Kebiasaan makan anak GPPH yang mengandung asam amino, mencapai posisi tertinggi pada kategori jarang. Hal ini berarti, sebanyak 252 dari 333 siswa SD beberapa kali dalan seminggu mengonsumsi makanan yang mengandung asam amino.

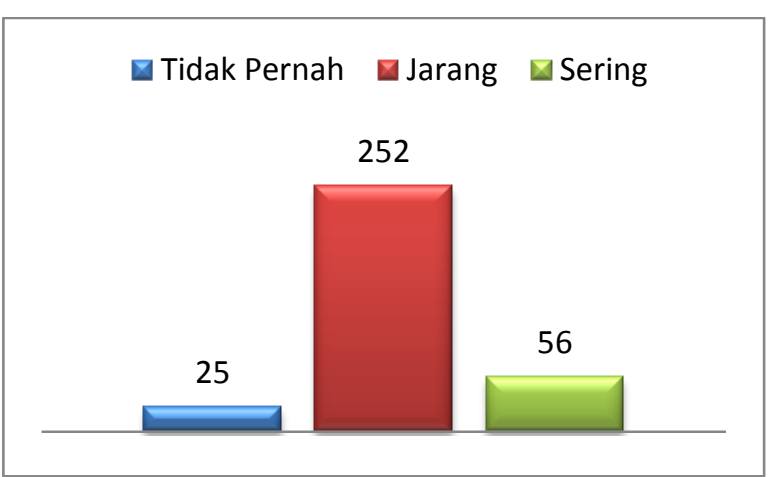

Gambar 6. Kebiasaan makan anak GPPH Makanan mengandung asam amino 
Terdapat begitu banyak makanan/ minuman yang dikonsumsi mengandung asam amino. Makanan/minuman yang tercantum dalam kuesioner mengandung asam amino, adalah; susu kedelai, kacang almond, kacang tanah, kacang mede, kacang tanah, sayur labu siam, sayur bayam dan sayur jagung.

Kebiasaan makan anak GPPH yang mengandung asam salisilat mencapai posisi yang paling tinggi pada kategori jarang yakni sebesar 187 siswa. Peringkat ini disusul oleh dua posisi lainnya yang hampir berimbang, yakni sering sebanyak 84 siswa dan tidak pernah sebanyak 62 siswa. Hal ini berarti, cukup banyak siswa yang mengonsumsi asam salisilat beberapa kali dalam seminggu. Makanan mengandung asam salisilat yang tercantum dalam kuesioner ialah: buah stroberi, buah bluberi, buah kiwi, buah tomat, buah jeruk, dan sayur buncis.

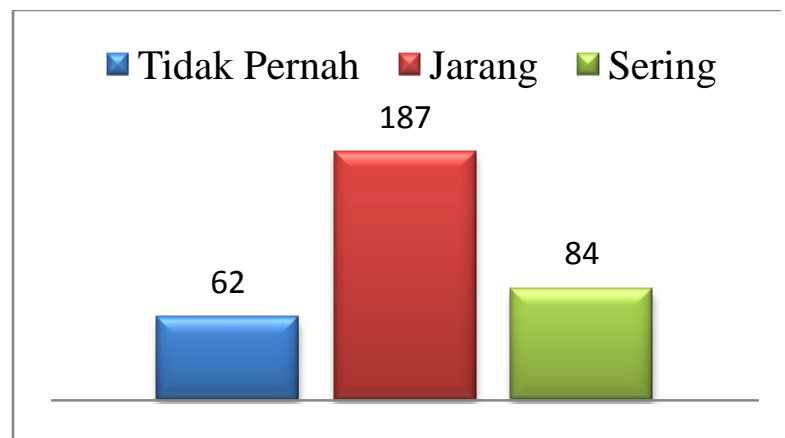

Gambar 7. Kebiasaan makan anak GPPH makanan mengandung asam salisilat

Berdasarkan penelitian sebelumnya, data yang didapatkan untuk deteksi dini pada anak GPPH di 20 sekolah di Manado, terdapat 646 dari 5725 siswa SD yang terdeteksi mengalami GPPH. Angka yang ditunjukkan menggambarkan bahwa $11,28 \%$ anak usia sekolah dari 20 SD yang berada di kota Manado, Sulawesi Utara menyandang GPPH. Persentase tersebut cukup sesuai dan mewakili penelitian sebelumnya di Jakarta yang mendapatkan prevalensi anak GPPH sebesar 4-12\% dengan estimasi 8-10\%.'

Kuesioner yang dibagikan peneliti untuk mengetahui kebiasaan makan pada anak GPPH, dibagikan kepada 646 siswa, namun hanya 333 kuesioner yang diambil sebagai sampel karena sebagian besar kuesioner tidak dikembalikan, data yang diisi tidak lengkap, atau karena kriteria eksklusi lainnya. Sampel yang digunakan untuk penelitian sebesar 51,55\% dari sampel yang seharusnya diharapkan, namun sampel tersebut dinilai sudah mencukupi untuk mendeskripsikan gambaran pola makan pada anak GPPH.

Kandungan gula yang berlebih, cokelat, kandungan zat pewarna makanan, asam oksalat, asam sitrat, zat pengawet buatan dan masih banyak lagi; diyakini dapat mengakibatkan anak menjadi semakin hiperaktif. ${ }^{6}$ Namun setelah melalui berbagai rangkaian penelitian, hal tersebut tidak membuahkan hasil yang signifikan. Baik dengan pengurangan konsumsi jumlah zat yang dianggap berpengaruh terhadap tingkat hiperaktivitas seseorang, hingga penambahan vitamin dan mineral, tidak begitu berpengaruh dengan tingkat hiperaktivitas seseorang. ${ }^{9}$ Perubahan pola makan di atas nampaknya hanya berpengaruh pada beberapa anak, terutama dengan keadaan hipersensitivitas/alergi terhadap zat-zat makanan tertentu. ${ }^{11}$

Data yang didapatkan mengenai kebiasaan makan untuk anak GPPH terhadap makanan yang mengandung pengawet dan pewarna buatan menunjukkan bahwa sebagian besar anak jarang memakan makanan atau minuman yang mengandung pengawet dan pewarna buatan. Hal ini menggambarkan juga bahwa penelitian dan artikel yang telah ada sebelumnya yang berpendapat bahwa tidak ada keterkaitan antara konsumsi makanan dan minuman berpengawet dan berpewarna buatan dengan tingkat hiperaktivitas seorang anak, mungkin bisa dibenarkan.

Data yang didapatkan untuk kebiasaan makan anak GPPH yang mengandung pemanis buatan, sebagian besar anak juga jarang mengonsumsi makanan berpemanis buatan layaknya cokelat dan permen atau lollipop. Sebagian anak GPPH bahkan tidak pernah makan cokelat atau permen dan lollipop. 
Kebiasaan makan anak GPPH terhadap makanan tinggi karbohidrat, seperti; nasi, roti dan sereal gandum, sangat sering dikonsumsi. Sebagai Bangsa Indonesia, memang umumnya akan mengonsumsi nasi sebagai makanan pokok setiap hari. Hal yang mengejutkan ialah pada pengumpulan data didapatkan beberapa anak yang jarang mengonsumsi nasi dan roti setiap hari. Siswa yang jarang tidak mengonsumsi nasi putih atau roti, mengonsumsi kentang dan jagung sebagai pengganti.

Kebiasaan makan anak GPPH terhadap makanan yang mengandung kasein seperti; susu, keju, krim susu dianggap memengaruhi anak autisme, namun penelitianpenelitian juga tetap dilakukan untuk mengetahui dampak yang diakibatkan konsumsi kasein pada anak GPPH. Hasil dari kuesioner yang telah dibagikan menunjukkan bahwa anak GPPH jarang mengonsumsi kasein. Sebagian besar yang mengonsumsi kasein hanya terbatas pada susu, dan tidak mengonsumsi produk olahan susu lainnya. Hal ini semakin menggambarkan bahwa pertimbangan memasukkan kandungan kasein agar dihindari oleh penderita GPPH semakin diragukan.

Asam amino, seperti yang terkandung pada susu kedelai, kacang-kacangan, juga bayam dan jagung, dinilai memengaruhi tingkat hiperaktivitas seorang anak. Data yang didapatkan dari kuesioner menunjukkan bahwa anak-anak GPPH jarang mengonsumsi makanan atau minuman yang mengandung asam amino. Semakin sulit untuk menimbang apakah asam amino benar-benar memengaruhi tingkat hiperaktivitas seseorang.

Kandungan yang terakhir yang dimasukkan dalam kolom kuesioner penelitian kebiasaan makan ialah asam salisilat. Asam salisiat, biasanya terdapat pada buah-buahan, seperti: stroberi, bluberi, tomat dan jeruk. Berdasarkan data yang didapat dari kuesioner, sebagian besar anak jarang mengonsumsi makanan yang mengandung asam salisilat. Sebagian lagi bahkan tidak pernah memakan makanan yang mengandung asam salisilat. Hal ini juga menyangsikan untuk menyimpulkan asam salisilat berpengaruh terhadap GPPH.

\section{SIMPULAN}

Berdasarkan data yang didapatkan melalui pembagian kuesioner kebiasaan makan dapat disimpulkan bahwa anak GPPH di Kota Manado sangat sering mengonsumsi makanan mengandung karbohidrat tinggi, cukup sering mengonsumsi makanan/ minuman mengandung kasein, pemanis buatan, dan asam salisilat, serta dapat dikatakan cukup jarang mengonsumsi makanan/minuman mengandung asam amino.

\section{DAFTAR PUSTAKA}

1. Wiguna, T. Buku Ajar Psikiatri. In: Elvira, SD, Gitayanti H, editors. Psikiatri Anak: Gangguan Pemusatan Perhatian dan Hiperaktivitas. Edisi Kedua. Jakarta: Badan Penerbit Fakultas Kedokteran Universitas Indonesia, 2014; p. 483-97.

2. Diagnostic and Statistical Manual of Mental Disorders (4th ed). Text Revision. Washington, DC: American Psychiatric Association, 2000.

3. Diagnostic and Statistical Manual of Mental Disorders (5th ed). Washington, DC: American Psychiatric Association, 2013

4. Understanding ADHD informations for parents about Attention-Deficit/Hiperactivity Disorder. American Psychiatric Association, 2007.

5. Indriyani SAK, Soetjiningsih IGA, Endah A, Trisna IGA W. Prevalensi dan faktor-faktor risiko Gangguan Pemusatan Perhatian Anak dan Hiperaktivitas di Klinik Tumbuh Kembang RSUP Sanglah Denpasar. Sari Pediatri. 2008;9(5):335-41.

6. Jacobson MF, David S. Diet, ADHD \& Behavior. Washington, DC: Center for Science in the Public Interest, 2009.

7. Harvard Mental Health Letter. Diet and attention deficit hyperactivity disorder. Havard: Harvard Medical School, 2009. Harvard Health Publication. Available from: www.health.harvard.edu/newsletters/ha rvard_mental_health_letter/2009/june

8. Miller MC. FDA panel finds no link between 
artificial food colorings and hiperactivity in most children. Harvard Health Publication Blog, 2011.

9. American Academy of Pediatrics. Your child's diet: A cause and a cure of ADHD? America: Healthychildren.org, 2015.

10. Bhandari, S. ADHD in Children Health Center Can You Prevent ADHD?
WebMD: LLC, 2014.

11. National Collaborating Centre for Mental Health. Attention-Deficit Hyperactivity Disorder Diagnosis and management of ADHD in children, young people and adults. United Kingdom: The British Psychological Society and The Royal College of Psychiatrists, 2009. 